\title{
Occurrence and pathogenicity of Pythium spp. in seedling roots of winter rye
}

\author{
MAURITZ VESTBERG \\ Agricultural Research Centre of Finland, Central Finland Research Station, \\ SF-41340 Laukaa, Finland
}

\begin{abstract}
Seedlings of winter rye collected from yellowing patches during October to November 1985-1987 showed oospores of Pythium species in apparently healthy as well as in discolored roots. Examination of 1550 root pieces of rye on CMA yielded fungi belonging to 35 genera. The most commonly isolated ones were Fusarium spp, Penicillium spp, Mucor spp, Mortierella spp. and Cladosporium spp. Pythium spp. were isolated from 35 root pieces on CMA. Identified species were $P$. splendens, $P$. irregulare, $P$. dissimile, a species resembling $P$. aristosporum and a species resembling $P$. ultimum. In in vitro and in vivo, tests on the cereals winter rye, spring wheat, oats and barley the pathogenicity of some Pythium isolates varied from high ( $P$. splendens, $P$. irregulare) to moderate (P. irregulare, $P$. dissimile) and low (a species resembling $P$. ultimum).
\end{abstract}

Index words: Pythium, pathogenicity, in vitro, in vivo winter rye, spring wheat, oats, barley

\section{Introduction}

Pythium species are common in agricultural soils and they parasitize a wide range of hosts (DomsCH et al. 1980). All spring and winter small grains and forage grasses are susceptible to root rot caused by one or several Pythium species acting singly or in combination (WIESE 1977).

Root rot on rye caused by species of Pythium has been reported only in a few cases. The species Pythium aphanidermatum (Edson) Fitz (Sechler \& LuKe 1967) and P. myriotylum Drechs. (LitTrell \& McCarter
1970, Mitchell 1975) have caused seedling damping-off and root rot in the southern parts of the U.S.A.

Several species of Pythium cause a browning root rot in barley. The disease has been encountered in the U.S.A. (BRUEHL 1955, Kilpatrick 1968, Mathre 1982, Bratolov. EAnU and Wallace 1985), Canada (McKeEN 1977), Argentina (FrezzI 1956), England (Waller 1979) and Australia (Dewan and Sivasithamparam 1988). $P$. arrhenomanes Drechs., $P$. aphanidermatum, $P$. graminicola 
Subr., P. irregulare Buisman, P. splendens Braun, $P$. tardicrescens Vanterpool and $P$. volutum Vanterpool \& Truscott are the most important species reported to be pathogenic on barley.

Browning root rot of wheat also has a world-wide distribution, and it has caused damage to wheat seedlings in the U.S.A. (Kilpatrick 1968, Chamswarng and CoOK 1985), England (WALler 1979), Austria (Glaeser 1979) and Australia (Dewan and Sivasithamparam 1988). More than ten species of Pythium have been reported to cause root rot, seed rot and damping-off in wheat seedlings. The most extensively documented wheat pathogens are $P$. arrhenomanes, $P$. aphanidermatum, $P$. graminicola, $P$. myriotylum Drechs. and P. volutum (WIESE 1977).

In oats, root rot has been caused by the species $P$. debaryanum Hesse (Welch 1945), P. aphanidermatum and $P$. splendens (KILPATRICK 1968).

In autumn 1984, patches of yellowed and stunted rye plants were observed in rye fields in southern Finland (Bremer and VestberG 1986). Electron microscopy revealed two types of virus particles in the leaves and roots of the yellowed rye seedlings. No virus vector, e.g. Polymyxa graminis Ledingham, was observed, only indications of fairly abundant occurrence of Pythium spp in roots of yellowed rye seedlings.

The aim of this study was to isolate and to identify species of Pythium from roots of rye seedlings. Introductory pathogenicity tests were conducted with some isolates on rye, barley, oats and winter wheat.

\section{Materials and methods}

\section{Sampling and sample treatment}

Seedling samples were collected from yellowing patches of winter rye fields during October to November 1985-87 and in May 1987 in southern and central Finland. The localities numbered 12, 23, 9 and 19 in autumn
1985, autumn 1986, autumn 1987 and spring 1987 , respectively.

The roots were rinsed thoroughly in tap water. One half of the root sample was examined with a compound microscope. From the other half of the sample, discoloured pieces (approx. $0.5 \mathrm{~cm}$ long) of fine roots, including healthy and discolored ones, were transferred to water agar (WA) without any surface sterilization or antibiotic treatment. The fungi were transferred from the WA to corn meal agar (CMA) for identification.

\section{Studies on Pythium strains}

Morphological characteristics of the strains of Pythium spp. were determined on 4-week cultures on CMA and on 9-day cultures in water. The water cultures were established by transferring a small piece of culture $(1 \mathrm{~cm}$ in diameter) on CMA beneath an autoclaved piece of young rye leaf, cv 'Dan Kowskie Zlote' into a Petri dish containing autoclaved water. The water consisting of "pond water" and destilled water (1:1) (Van der PlaAtsNITERINK 1981) was changed twice daily. On these occasions sexual and asexual structures of Pythium isolates were distinguished on the piece of rye.

\section{Pathogenicity of Pythium strains in vitro}

The pathogenicity of four Pythium strains (P1, P2, P3, P9) isolated from winter rye was tested in vitro in four replicates on barley cv 'Kymppi', oats cv 'Hankkijan Vouti', spring wheat cv 'Tähti' and winter rye cv 'Dan Kowskie Zlote'. A system of hanging file folders made of filter paper was arranged in a water bath with $5 \mathrm{~cm}$ of water at the bottom. Due to water suction the filter paper remained wet when the water level was maintained at $5 \mathrm{~cm}$. In each folder five surface sterilized seeds ( $1 \mathrm{~min}$ in $1 \% \mathrm{NaOCl}$ ) were applied between the two layers, $2 \mathrm{~cm}$ from the top. Inocula of Pythium (1 $\mathrm{cm}$ in diameter), 1 -month culture on CMA, were placed $2 \mathrm{~cm}$ 
beneath the cereal seed. Paper clips were used to bring the two layers of the hanging folder close to each other. The whole experiment consisted of six water baths with 16 hanging file folders in each. After three days of incubation in darkness the baths were placed into a growth chamber with a 16-h daylength and a light intensity of approx 5000 lux. The shoot lengths were measured seven days after onset of the experiment. Final observations of root and shoot lengths, disease symptoms and infection of Pythium were made four days later. Disease symptoms in shoots and roots of seedlings were estimated visually on a scale from 0 to 2 :

$0=$ Healthy

$1=$ Moderately discolored

$2=$ Highly discolored

The disease index (DI) of a treatment was calculated as the mean of altogether 20 seedlings belonging to four replicates.

\section{Pathogenicity of Pythium strains in vivo}

The pathogenicity of three Pythium isolates (P2, P9, P17) was tested in vivo in six replicates on the same species and cultivars of cereals as in the in vitro experiment. Surface sterilized seeds ( $1 \mathrm{~min}$ in $1 \% \mathrm{NaOCl}$ ) were pregerminated for five days at room temperature (about $22^{\circ} \mathrm{C}$ ) until the seedling was approx. $4 \mathrm{~cm}$ long; equally long seedlings were thereafter planted into white plastic pots $(3 \mathrm{dl}$, $5.5 \mathrm{~cm}$ deep) at a depth of $2 \mathrm{~cm}$, five in each. The pots were filled with a sand-vermiculiteleca gravel mixture (1:1:1). The inoculum, a piece of Pythium culture on CMA $(1 \mathrm{~cm}$ in diameter, 14-day old culture) was placed $1 \mathrm{~cm}$ beneath the seed. The pots were fertilized with the slow-release fertilizer osmocote, $2 \mathrm{~kg} / \mathrm{m}^{3}$, and were kept in a glass house at a temperature of about $20^{\circ} \mathrm{C}$ throughout the experiment. Supplementary light was given to get a daylength of $16 \mathrm{~h}$.

The experiment started on the 19th of October, 1987, and ended eight days later, when the disease symptoms in roots and on leaves, as well as seedling lengths and dry weights of above ground plant parts and roots were determined.

The disease symptoms in roots were estimated visually in the same way as in the in vitro experiment. The DI of a treatment was calculated as the sum of disease symptoms in all seedlings in that treatment, altogether 30 seedlings.

\section{Statistical analysis}

Statistical analysis of the results of the pathogenicity experiments was done using the analysis of variance. Means were compared with Duncan's multiple range test.

\section{Results}

Direct microscopy of seedling roots of rye

Although all seedling samples of rye collected in autumn 1985-1987 were taken from yellow patches in the field, the majority $(70.5 \%)$ of samples contained apparently healthy roots (Table 1). Highly discolored roots were found in five samples out of 44 samples. Oospores of Pythium were detected in healthy as well as in moderately or highly discolored roots. However, severe infection of Pythium was found only in samples with highly discolored roots. On the other hand, no oospores of Pythium were detected in two samples with highly discolored roots (Table 1).

Including the seedling samples collected in spring 1987, which makes a total of 63 samples studied by direct microscopy, the samples containing Pythium spp. in roots numbered as follows:

No infection of Pythium detected: 34 samples

\begin{tabular}{|c|c|c|c|}
\hline Mild & ") & 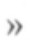 & $: 20$ \\
\hline Moderate & $"$ & » & : 7 \\
\hline Severe " & 》) & 》) & : \\
\hline
\end{tabular}


Table 1. Occurrence of oospores of Pythium in roots of rye seedlings collected from 44 localities in OctoberNovember $1985-87$.

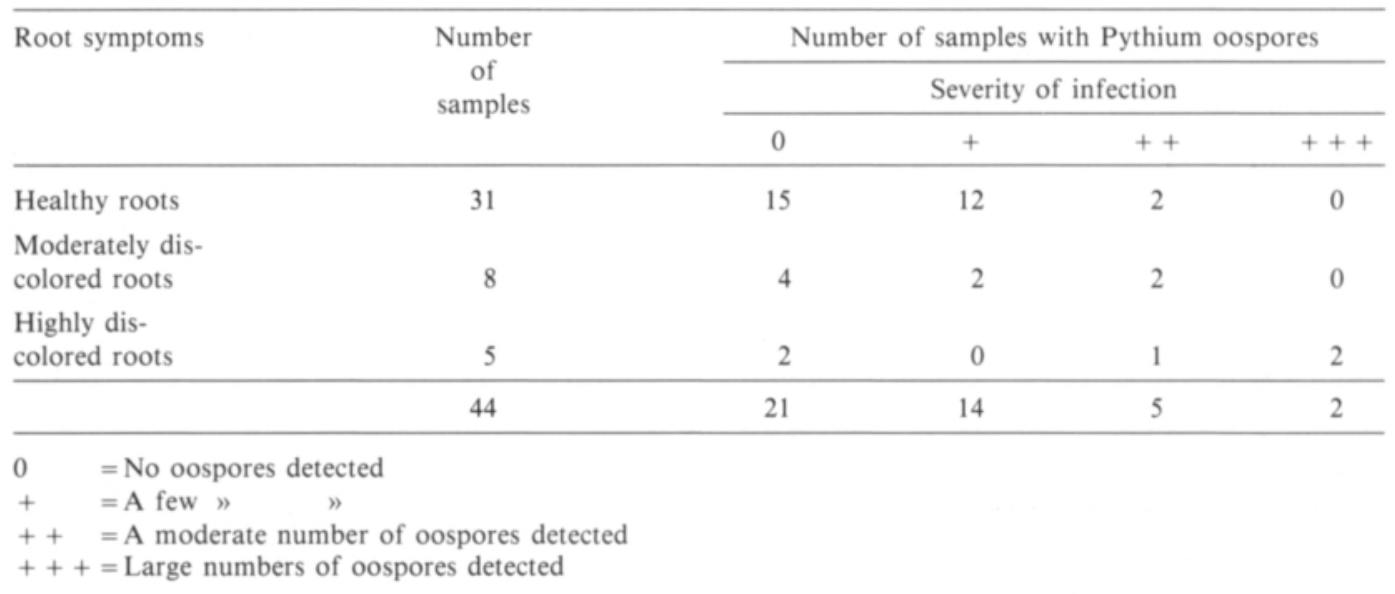

\section{Fungi identified on CMA}

From seedling samples collected in the autumn of 1985 and 1986 and in spring 1987 altogether 1550 root pieces were examined on CMA for fungi. Fungi belonging to 35 genera were found (Table 2).

Among 884 root pieces studied from the autumn samples of 1985 Fusarium spp (84 pieces), Penicillium spp. (65 pieces) and Mucor spp. (45 pieces) were the most common fungi. In 1986, 423 samples were studied and the most common fungi were the same as in 1985, i.e. Fusarium spp. (31 pieces), Penicillium spp. (25 pieces) and Mucor spp. (24 pieces). The result for 243 root pieces evaluated in spring 1987 was Mortierella spp. (79 pieces), Cladosporium (76 pieces) and $F u$ sarium spp. (74 pieces).

The number of fungi per root piece averaged 0.4 and 0.3 for autumns 1985 and 1986 respectively, while in spring 1987 there were 2.1 fungi per root piece.

Pythium spp. were identified in altogether 27 root pieces, i.e. in five pieces in autumn 1985, 13 pieces in autumn 1986 and nine pieces in spring 1987.

\section{Studies on Pythium spp}

Twenty-seven fungal isolates on CMA were identified as Pythium spp. Eight of these representing several species of Pythium were obtained in pure culture (Table 3 ).

\section{Pathogenicity of Pythium strains in vitro}

The "hanging file folder" method was successful. Infection of Pythium was noticed in all cereals tested. Of the isolates, P1 (P. splendens) caused very extensive infection in all cereals, $87.5 \%$ of seedlings in this treatment being affected. On the other hand, P3 (isolate resembling $P$. ultimum) caused very low or no infection at all. The isolates P2.(P. irregulare) and $\mathrm{P} 9(P$. dissimile) gave rise to infection in about $50 \%$ of the seedlings (Table 4).

Oats was the healthiest cereal, infection occurring in $37.5 \%$ of seedlings, while spring wheat was the most extensively infected, $(60.3 \%)$.

Host specificity was observed especially for isolates P2 and P3. P2 infected winter rye by $67 \%$, while it caused no infection in barley. P3 caused no infection in oats but a slight or moderate infection in barley (Table 4).

Out of four isolates tested, only P1 caused a significant reduction in shoot and root length (Table 5). It also caused more leaf symptoms than the control treatment. Inverse- 
Table 2. Fungi isolated from roots of rye collected in autumn 1985 and 1986 and in spring 1987.

\begin{tabular}{|c|c|c|c|c|}
\hline \multirow[t]{2}{*}{ Fungus } & \multicolumn{4}{|c|}{ Number of isolations } \\
\hline & 1985 & 1986 & 1987 & Total \\
\hline Absidia $\mathrm{sp}$ & 3 & & 2 & 5 \\
\hline Acremonium spp & 22 & & 36 & 58 \\
\hline Alternaria alternata $(\mathrm{Fr}$.$) Keissler$ & 1 & 5 & 4 & 10 \\
\hline Aspergillus sp. & 1 & & & 1 \\
\hline Aureobasidium pullulans (de Bary) Arnaud & 1 & & & 1 \\
\hline Broomella acuta Shoem. \& E. Müll. & & & 3 & 3 \\
\hline Chaetomium globosum Kunze ex Steud. & 2 & & & 2 \\
\hline Cladosporium spp. & 11 & 9 & 76 & 96 \\
\hline \multicolumn{5}{|l|}{ Cochliobolus sativus (Ito \& Kuribayashi) } \\
\hline Drechsler ex Dastur & 10 & & 5 & 15 \\
\hline Coniotyrium sp. & & 4 & & 4 \\
\hline Cylindrocarpon spp. & 3 & 1 & 8 & 12 \\
\hline Dendryphion nanum (Nees ex Gray) & & & 1 & 1 \\
\hline Doratomyces sp. & 1 & 1 & & 2 \\
\hline Epicoccum purpurascens Ehrenb. ex Schlecht. & 6 & 2 & 8 & 16 \\
\hline Fusarium avenaceum (Fr.) Sacc. & 34 & 9 & & 43 \\
\hline F. culmorum (W.G. Sm.) Sacc. & 21 & 6 & & 27 \\
\hline F. graminearum Schwabe & & 2 & & 2 \\
\hline F. oxysporum Schlecht. & 3 & 1 & & 4 \\
\hline F. sambucinum Fuck. & 4 & & & 4 \\
\hline F. solani (Mart.) Sacc. & 1 & & & 1 \\
\hline Fuasarium sp. & 21 & 13 & 66 & 100 \\
\hline Geotrichum sp. & 1 & & 1 & 2 \\
\hline Gliocladium sp. & 2 & 6 & 1 & 9 \\
\hline Humicola fuscoatra Traaen & & & 5 & 5 \\
\hline Mortierella spp. & 25 & & 79 & 104 \\
\hline Mucor spp. & 45 & 24 & 52 & 121 \\
\hline Papulaspora sp. & 19 & 5 & 10 & 34 \\
\hline Penicillium spp. & 65 & 25 & 41 & 131 \\
\hline Pestalotia $\mathrm{sp}$. & 1 & & & 1 \\
\hline Phoma spp. & 20 & & 9 & 29 \\
\hline Pythium spp. & 5 & 13 & 9 & 27 \\
\hline Rhizoctonia solani Kühn & 10 & & & 10 \\
\hline Rhizopus nigricans Ehrenb. & 2 & & 4 & 6 \\
\hline Scopulariopsis brevicaulis (Sacc.) Bain & 1 & & & 1 \\
\hline Sporotrix schenckii Hektoen \& Perkins & & & 12 & 12 \\
\hline Torula herbarum Pers. ex Gray & & 1 & 3 & 4 \\
\hline Trichocladium asperum Harz & & & 6 & 6 \\
\hline Trichoderma viride Pers. ex Gray & 26 & 8 & 61 & 95 \\
\hline Ulocladium consortiale (Thüm.) Simmons & 2 & & 6 & 8 \\
\hline Verticillium sp. & 16 & & 3 & 19 \\
\hline Zygorhynchus sp. & 1 & & 9 & 10 \\
\hline Total number of root pieces examined & 884 & 423 & 243 & 1550 \\
\hline
\end{tabular}

ly, isolate P9 gave rise to the highest root symptom index, causing brown roots especially in barley. Both P9 and P1 increased the severity of root damage.

\section{Pathogenicity of Pythium strains in vivo}

Isolate P9 significantly decreased shoot dry weight, while the isolates $\mathrm{P} 2$ and $\mathrm{P} 17$ (P. ir- regulare) caused an increase as compared to the control. In root dry weight there were no decreases due to Pythium isolates, but P17 significantly increased root dry weight (Table 6).

All isolates slightly decreased seedling length, isolates P17 and P9 significantly so, as compared to the control.

The leaves and seedling bases showed no symptoms. 
Table 3. Morphological characteristics of Pythium isolates from rye seedlings.

\begin{tabular}{|c|c|c|}
\hline Characteristics of isolate & Isolate & Tentative name \\
\hline $\begin{array}{l}\text { Growth } 13.4 \mathrm{~mm} / \text { day on CMA. Oogonia } 34.3 \mu \mathrm{m}(26.2-43.6) \text {. Several } \\
\text { in clusters. Older oogonia and oospores somewhat pigmented. Hyphal } \\
\text { swellings. Oospores } 26.3 \mathrm{~m}(22.5-35.9) \text {. Antheridia broad, sac-like, gener- } \\
\text { ally } 2-5 \text { /oogonium. No growth on rye leaf in water. No asexual structures. }\end{array}$ & P1 & P. splendens \\
\hline $\begin{array}{l}\text { Growth } 26.8 \mathrm{~mm} / \text { day on CMA. Oogonia } 22.0 \mu \mathrm{m}(19.4-25.2) \text {, terminal } \\
\text { or intercalary, of varying appearance, with one or a few finger-like projec- } \\
\text { tions. Oospore } 19.2 \mu \mathrm{m}(15.5-21.3) \text {. Antheridia } 1-2 / \text { oogonium, mostly } \\
\text { arising from the same hypha as the oogonium. Scanty growth on leaf of } \\
\text { rye in water. No asexual structures. }\end{array}$ & $\begin{array}{l}\text { P2, P10 } \\
\text { P17 }\end{array}$ & P. irregulare \\
\hline $\begin{array}{l}\text { Hyphal growth } 13.5 \mathrm{~mm} / \text { day on CMA. Small oogonia with thin wall. No } \\
\text { antheridia or rarely } 1 / \text { oogonium, big. Oospores } 13.7 \mu \mathrm{m}(8.7-18.4) \text {. } \\
\text { Scanty hyphal growth on rye leaf in water. Sporangia irregular, subglobose } \\
\text { forming complex structures. No zoospores observed. }\end{array}$ & P9 & P. dissimile \\
\hline $\begin{array}{l}\text { Hyphal growth } 27.1 \mathrm{~mm} / \text { day on CMA. Oogonia } 25.0 \mu \mathrm{m}(17.2-29.4) \text {. } \\
\text { Antheridia almost thread-like with long stalk, several/oogonium, diffi- } \\
\text { cult to observe. Oospores } 22.6 \mu \mathrm{m}(19.4-26.7) \text {. Sickle-shaped appres- } \\
\text { soria at bottom of Petri dish, in clusters. Moderate growth on leaf of rye } \\
\text { in water. No asexual structures. }\end{array}$ & $\begin{array}{l}\text { P13, } \\
\text { P15 }\end{array}$ & $\begin{array}{l}\text { Pythium sp. } \\
\text { Resembling } P \text {. aris- } \\
\text { tosporum }\end{array}$ \\
\hline $\begin{array}{l}\text { Growth } 15.4-17.5 \mathrm{~mm} / \text { day on CMA. Oospores } 18.8 \mu \mathrm{m}(15.8-20.7) \\
\text { with a thick wall. Antheridia seldom visible, with a long bent and irregu- } \\
\text { lar stalk, 1/oogonium. Club-shaped appressoria at bottom of Petri dish. } \\
\text { Good growth on rye leaf in water. No asexual structures. }\end{array}$ & P3 & $\begin{array}{l}\text { Pythium sp. } \\
\text { Oospore resembling } \\
\text { P. ultimum }\end{array}$ \\
\hline
\end{tabular}

Table 4. Percentage of cereal seedling roots infected by Pythium in the in vitro experiment.

\begin{tabular}{lccccc}
\hline Cereal & \multicolumn{5}{c}{ Percentage of roots infected } \\
\cline { 2 - 6 } & \multicolumn{5}{c}{ Pythium isolates } \\
\cline { 2 - 6 } & P1 & P2 & P3 & P9 & Mean \\
\hline Barley & 92 & 0 & 25 & 75 & 48.0 \\
Oats & 75 & 50 & 0 & 25 & 37.5 \\
Spring wheat & 83 & 75 & 8 & 75 & 60.3 \\
Winter rye & 100 & 67 & 17 & 33 & 54.3 \\
\hline Mean & 87.5 & 48.0 & 12.5 & 52.0 \\
\hline
\end{tabular}

Seedlings showed few shoot and root symptoms in the in vivo experiment. The disease severity index of roots (maximum 60) was calculated as the sum of DI of 30 seedlings. Isolate P17 had a somewhat higher root DI than the control and the other Pythium isolates, 3.8 as compared to 2.6, 2.8 and 2.5 for the control, P2 and P9, respectively. Barley had on average the most diseased roots, while spring wheat had the healthiest ones (Table 6).

\section{Discussion}

The aim of this investigation was to study the occurrence and the importance of Pythium spp. in roots of rye seedlings. Because Pythium spp. are often relatively infrequently isolated from surface sterilized roots (WALler 1968), an isolation method using no chemical compounds or antibiotics was chosen. The method yielded 35 genera of soil borne fungi. Most of them were classified as common saprophytic soil fungi, while other genera such as Fusarium spp., which was found quite frequently, and Pythium spp. often act as pathogens or minor pathogens in cereal roots (SALT 1979).

With the exception of $P$. dissimile, all the Pythium species identified, i.e. P. splendens. $P$. irregulare, $P$. dissimile, a species resembling $P$. aristosporum and a species resembling $P$. ultimum occur in roots of cereals in various parts of the world (CHAMSWARNG \& Cook 1985 Dewan \& Sivasithamparam 1988, Kilpatrick 1968 Singleton \& Ziv 1981). 
Table 5. The effect of inoculation with strains of Pythium isolated from winter rye on shoot and root length, shoot and root symptoms in four cereal crops in vitro.

\begin{tabular}{|c|c|c|c|c|c|}
\hline \multirow[t]{3}{*}{ Cereal } & \multicolumn{5}{|c|}{ Treatment } \\
\hline & \multirow[b]{2}{*}{ Control } & \multicolumn{4}{|c|}{ Inoculation with Pythium } \\
\hline & & P1 & $\mathrm{P} 2$ & P3 & P9 \\
\hline & $\begin{array}{l}\text { Shoot } \\
\text { length }\end{array}$ & \multicolumn{4}{|c|}{ Difference from control } \\
\hline Barley & $20.1^{\mathrm{a}}$ & $-1.4^{\mathrm{a}}$ & $+0.2^{\mathrm{a}}$ & $-0.1^{\mathrm{a}}$ & $-0.5^{\mathrm{a}}$ \\
\hline Oats & $18.3^{\mathrm{a}}$ & $-4.3^{b}$ & $-0.8^{a}$ & $-0.8^{\mathrm{a}}$ & $-0.9^{a}$ \\
\hline Spring wheat & $21.4^{a}$ & $-4.6^{\mathrm{b}}$ & $+0.6^{\mathrm{a}}$ & $+0.6^{\mathrm{a}}$ & $-0.3^{a}$ \\
\hline Winter rye & $17.8^{\mathrm{a}}$ & $-2.7^{a}$ & $+1.7^{a}$ & $+0.4^{a}$ & $-1.3^{\mathrm{a}}$ \\
\hline \multirow[t]{2}{*}{ Mean } & $19.4^{\mathrm{a}}$ & $-3.3^{b}$ & $+0.4^{\mathrm{a}}$ & $+0.2^{\mathrm{a}}$ & $-0.7^{\mathrm{a}}$ \\
\hline & $\begin{array}{l}\text { Root } \\
\text { length }\end{array}$ & \multicolumn{4}{|c|}{ Difference from control } \\
\hline Barley & $14.7^{\mathrm{a}}$ & $-2.2^{\mathrm{a}}$ & $-0.7^{\mathrm{a}}$ & $0.0^{\mathrm{a}}$ & $-0.9^{a}$ \\
\hline Oats & $9.4^{\mathrm{ab}}$ & $-1.0^{\mathrm{b}}$ & $-0.4^{\mathrm{ab}}$ & $+1.0^{\mathrm{a}}$ & $-0.1^{\mathrm{ab}}$ \\
\hline Spring wheat & $15.1^{\mathrm{a}}$ & $-1.8^{\mathrm{a}}$ & $0.0^{2}$ & $0.0^{\mathrm{a}}$ & $-2.9^{a}$ \\
\hline Winter rye & $10.8^{\mathrm{a}}$ & $-0.4^{a}$ & $-0.6^{a}$ & $-0.6^{\mathrm{a}}$ & $-1.2^{\mathrm{a}}$ \\
\hline \multirow[t]{2}{*}{ Mean } & $12.5^{\mathrm{a}}$ & $-1.8^{b}$ & $-0.4^{\mathrm{a}}$ & $+0.1^{\mathrm{a}}$ & $-1.1^{\mathrm{ab}}$ \\
\hline & $\begin{array}{c}\text { Shoot } \\
\text { DI }\end{array}$ & \multicolumn{4}{|c|}{ Difference from control } \\
\hline Barley & 0.0 & +0.1 & 0.0 & 0.0 & 0.0 \\
\hline Oats & 0.0 & +0.2 & 0.0 & 0.0 & 0.0 \\
\hline Spring wheat & 0.0 & +0.4 & +0.1 & 0.0 & +0.1 \\
\hline Winter rye & 0.3 & +0.8 & -0.1 & +0.2 & +0.3 \\
\hline \multirow[t]{2}{*}{ Mean } & 0.06 & +0.31 & +0.02 & +0.07 & +0.10 \\
\hline & $\begin{array}{c}\text { Root } \\
\text { DI }\end{array}$ & \multicolumn{4}{|c|}{ Difference from control } \\
\hline Barley & 0.1 & +0.8 & +0.2 & +0.2 & +1.4 \\
\hline Oats & 0.2 & +0.4 & -0.2 & +0.1 & -0.1 \\
\hline Spring wheat & 0.1 & -0.1 & +0.1 & +0.1 & +0.5 \\
\hline Winter rye & 0.2 & +0.2 & -0.1 & -0.1 & 0.0 \\
\hline Mean & 0.15 & +0.31 & -0.04 & +0.08 & +0.44 \\
\hline
\end{tabular}

* Values in rows marked with the same letter do not differ significantly at $p=0.05$.

Direct microscopy revealed easily oospores of Pythium in fine roots of rye seedlings, but a lower percentage of Pythium species was obtained on CMA and only a few isolates could be studied in pure culture. This indicates that on CMA the growth of the Pythium was disturbed or even overgrown by the saprophytic fungi, and some kind of surface sterilization of root pieces could have increased the number of isolates obtained in pure culture.

Oospores of Pythium were detected in brown as well as in apparently healthy roots, a fact which supports the findings of W WLLER (unpublished, ref. SALt 1979). This also suggests that in the roots of rye seedlings Pythium may rather be a minor pathogen than a 
Table 6. The effect of inoculation with three strains of Pythium isolated from winter rye on shoot and root dry weight, seedling length and root disease index (DI) in four cereal crops in vivo.

\begin{tabular}{|c|c|c|c|c|}
\hline \multirow[t]{3}{*}{ Cereal crop } & \multicolumn{4}{|c|}{ Treatment } \\
\hline & \multirow[b]{2}{*}{ Control } & \multicolumn{3}{|c|}{ Pythium strain } \\
\hline & & P2 & P9 & P17 \\
\hline & $\begin{array}{l}\text { Shoot } \\
D M, g\end{array}$ & \multicolumn{3}{|c|}{ Difference from control } \\
\hline Barley & $0.50^{\mathrm{b}}$ & $+0.20^{\mathrm{a}}$ & $-0.05^{b}$ & $+0.11^{\mathrm{a}}$ \\
\hline Oats & $0.43^{\mathrm{a}}$ & $+0.06^{\mathrm{a}}$ & $-0.9^{b}$ & $+0.08^{\mathrm{a}}$ \\
\hline Spring wheat & $0.49^{\mathrm{a}}$ & $0.00^{\mathrm{a}}$ & $-0.11^{b}$ & $0.00^{\mathrm{a}}$ \\
\hline Winter rye & $0.45^{\mathrm{ab}}$ & $+0.07 \mathrm{a}$ & $-0.06^{\mathrm{b}}$ & $+0.01^{\mathrm{ab}}$ \\
\hline \multirow[t]{2}{*}{ Mean } & $0.47^{b}$ & $+0.08^{a}$ & $-0.08^{c}$ & $+0.05^{a}$ \\
\hline & $\begin{array}{c}\text { Root } \\
D M, g\end{array}$ & \multicolumn{3}{|c|}{ Difference from control } \\
\hline Barley & $0.21^{\mathrm{a}}$ & $+0.02^{\mathrm{a}}$ & $-0.01^{\mathrm{a}}$ & $+0.05^{\mathrm{a}}$ \\
\hline Oats & $0.18^{\mathrm{a}}$ & $-0.04^{\mathrm{a}}$ & $-0.01^{\mathrm{a}}$ & $+0.02^{\mathrm{a}}$ \\
\hline Spring wheat & $0.21^{\mathrm{ab}}$ & $-0.06^{b}$ & $-0.04^{b}$ & $+0.09^{\mathrm{a}}$ \\
\hline Winter rye & $0.16^{\mathrm{ab}}$ & $+0.02^{\mathrm{ab}}$ & $-0.02 b$ & $+0.06 \mathrm{a}$ \\
\hline Mean & $0.19^{b}$ & $-0.02^{\mathrm{b}}$ & $-0.02^{b}$ & $+0.05^{a}$ \\
\hline
\end{tabular}

\begin{tabular}{lcccc}
\hline & $\begin{array}{c}\text { Seedling } \\
\text { length, cm }\end{array}$ & \multicolumn{3}{c}{ Difference from control } \\
Barley & $37.6^{\mathrm{a}}$ & $-0.7^{\mathrm{a}}$ & $-0.5^{\mathrm{a}}$ & $-1.2^{\mathrm{a}}$ \\
Oats & $35.4^{\mathrm{a}}$ & $+1.0^{\mathrm{a}}$ & $-1.1^{\mathrm{a}}$ & $-1.5^{\mathrm{a}}$ \\
Spring wheat & $43.9^{\mathrm{a}}$ & $-2.7^{\mathrm{b}}$ & $-2.4^{\mathrm{b}}$ & $-2.5^{\mathrm{b}}$ \\
Winter rye & $34.2^{\mathrm{ab}}$ & $+0.9^{\mathrm{a}}$ & $+1.0^{\mathrm{ab}}$ & $-2.2^{\mathrm{b}}$ \\
\hline Mean & $37.8^{\mathrm{a}}$ & $-0.04^{\mathrm{bc}}$ & $-1.3^{\mathrm{bc}}$ & $-1.9^{\mathrm{c}}$
\end{tabular}

\begin{tabular}{lllll}
\hline & \multicolumn{3}{c}{ Root DI } \\
Barley & 5 & 5 & 5 & 7 \\
Oats & 2 & 3 & 2 & 4 \\
Spring wheat & 2 & 1 & 0 & 3 \\
Winter rye & 2 & 2 & 3 & 2 \\
\hline Mean & 2.6 & 2.8 & 2.5 & 3.8 \\
\hline
\end{tabular}

* Values in rows marked with the same letter do not differ significantly at $p=0.05$.

real damage causing pathogen. This role of Pythium was supported also by the findings in the in vivo and in vitro pathogenicity experiments, in which the pathogenicity of some Pythium isolates varied from pathogenic to beneficial. This kind of variation in pathogenicity is commonly documented (DEWAN and Sivasithamparam 1988, Kilpatrick 1968, Sin. GLETON and Ziv 1981). 


\section{References}

Bratoloveanu, J. \& Wallace, H.R. 1985. The influence of Pythium on the growth of barley seedlings as affected by soil water and inoculum density. Plant and Soil 85: 305-311.

Bremer, K. \& Vestberg, M. 1986. Two soil-borne viruses and their possible fungal vectors in Secale cereale in Finland. Research note. Ann. Agr. Fenn. 25: 31-35.

BRUeHL, G.W. 1955. Barley adaptation in relation to Pythium root rot. Phytopath. 45: 97-103.

Chamswarng, C \& CoOK, R.J. 1985. Identification and comparative pathogenicity of Pythium species from wheat roots and wheat-field soils in the pacific Northwest. Phytopath. 75: 821-827.

Dewan, M.M. \& Sivasithamparam, K. 1988. Pythium spp in roots of wheat and rye-grass in western Australia and their effect on root rot caused by Gaeumannomyces graminis var. tritici. Soil. Biol. Biochem. 20: $801-808$.

Domsch, K.H., Gams, W \& Anderson, T.H. 1980. Compendium of soil fungi. Academic press, London. 859 pp.

Frezzi, M.J. 1956. Especies de Pythium fitopatogenas identificadas en la Republica Argentina. (Phytopathogenic species of Pythium identified in the Argentine Republic). Rev. Invest. agric. 10: 113-241.

Glaeser, G. 1979. Bericht über das Auftreten wichtige Krankheiten und Schädlinge an Kulturpflanzen in Österreich im Jahre 1977. Pflanzenschutzberichte 45: $153-164$

KILPATRICK, R.A. 1968. Seedling raction of barley, oats, and wheat to Pythium species. Pl. Dis. Rep. 52: 209-212.

LitTrell, R.H. \& McCarter, S.M. 1970. Effect of soil temperature on virulence of Pythium aphanidermatum and Pythium myriotylum to rye and tomato. Phytopath 60: 704-707.

Mathre, D.E. 1982. Compendium of barley diseases. St. Paul, Minnesota. 78 pp.

McKeEn, W.E. 1977. Growth of Pythium graminicola in barley roots. Can. J. Bot. 55: 44-47.

Mitchell, D.J. 1975. Density of Pythium myriotylum oospores in soil in relation to infection of rye. Phytopath 65: 570-575.

SALT, G.A. 1979. The increasing interest in minor pathogens. In "Soil-borne plant pathogens". Eds SCHIP. PERS, B. \& Gams, W., 686 pp, Academic Press, New York. 289-312

Sechler, D. \& Luke, H.H. 1967. Stand loss of small grain in Florida. Plant Dis. Reptr. 52: 179-183.

Singleton, L.L. \& Ziv, O. 1981. Effects of Pythium arrhenomanes infection and root-tip amputation on wheat seedling development. Phytopath. 71: 316-319.

WALLer, J.M. 1968. Annual report of Rothamsted experimental station for 1967: 139.

- 1979. Observations on Pythium root rot of wheat and barley. Pl. Path. 28: 17-24.

Van der PlaAts-Niterink, A.J. 1981. Monograph of the genus Pythium. Studies in Mycology 21. 239 pp.

Welch, A. 1945. Pythium root necrosis of Oats. Iowa St. Coll. J. Sci. 29: 361-399.

WIESE, M.V. 1977. Compendium of wheat diseases. St. Paul, Minnesota. 106 pp.

Ms received April 6, 1990

\title{
SELOSTUS
}

\section{Rukiin oraiden juurissa esiintyvät Pythium- sienet ja niiden patogeenisuus viljalajeille}

\author{
Mauritz Vestberg \\ Maatalouden tutkimuskeskus, Keski-Suomen \\ tutkimusasema, \\ 41340 Laukaa
}

Etelä-Suomen ruispelloilla oli syksyllä 1984 monin paikoin kellastuneiden oraiden muodostamia laikkuja. Kellastuneiden oraiden juurissa havaittiin kahdenlaisia virushiukkasia. Samanaikaisesti etsittiin rukiin juurista virusvektoreiksi sopivia sieniä. Niitä ei kuitenkaan löytynyt.

Sen sijaan juurissa oli usein havaittavissa Pythium-sienen rakenteita.

Rukiin oraita kerättiin kellastuneista peltokohdista vuosina 1985-1987. Keruupaikkoja oli syksyllä 1985 12, syksyllă 198623 , syksyllä 19879 ja kevăällă 198719 . Osa 
näytteiden juurista tutkittiin suoraan stereomikroskoopilla ja osa juurista laitettiin maissiagarille. Pythiumsienten rakenteita esiintyi sekä terveen- ettă sairaannäkőisissä juurissa. Kuitenkin hyvin runsaita Pythium esiintymiă löytyi ainoastaan voimakkaasti tummuneista juurista. Maissiagarilla esitetyt sienet kuuluvat 35 sienisukuun. Năistă suurin osa lienee saprofyyttisiă maasieniă. Pythium-sientä eristettiin 27:stä juurenpalasta. Lajit olivat $P$. splendens, $P$. irregulare, $P$. dissimile, $P$. aristosporum 'ia muistuttava laji sekă $P$. ultimum 'ia muistuttava laji.

Neljän viljalajin (ruis, kevätvehnä, ohra, kaura) pato- geenisuustesteissä tulokset olivat vaihtelevia. In vitro testissä $P$. splendens oli hyvin patogeeninen kaikille viljalajeille, kun taas $P$. ultimum' ia muistuttava laji ei juuri infektoinut. In vivo testissä $P$. irregulare hieman lisäsi juurten tautisuusindeksiä.

Tutkimus osoitti, että Pythium-sieniä esiintyy melko yleisesti rukiin juurissa. Sienten todellista merkitystä on kuitenkin vaikea päătellă. Todennäköisesti ne kuuluvat siihen suureen maasienten ryhmảän, jotka ovat taudinaiheuttajia vain tietyissä sienille edullisissa olosuhteissa, ovat n.s. "minor patogeeneja". 